\title{
Evaluasi Perencanaan Jembatan Kereta Api Rangka Baja Double Track Tipe Welded Through Truss Bentang 50 meter
}

\author{
BADRIANA NURANITA, ERMA DESMALIANA, KENNY GESA
}

\author{
Program Studi Teknik Sipil, Institut Teknologi Nasional Bandung \\ Email: nuranitaana@itenas.ac.id
}

\begin{abstract}
ABSTRAK
Penelitian ini menganalisis perencanaan struktur atas jembatan kereta api rangka baja double track tipe Welded Through Truss (WTT) dengan bentang jembatan 50 m melalui Gambar Standar Tipikal Jembatan yang ada di lapangan. Analisis dan pembebanan jembatan sesuai kriteria teknis yang mengacu pada Lampiran Peraturan Menteri Perhubungan No. 60 Tahun 2012 tentang Persyaratan Teknis Jalur Kereta Api. Hasilnya dievaluasi dalam nilai tegangan dan defleksi. Hasil analisis menunjukan bahwa terdapat beberapa batang diagonal yang menghasilkan angka rasio tegangan > 1, sehingga perlu dilakukan penambahan tebal profil penampang atau juga menambahkan stiffener pada elemen-elemen jembatan yang kritis. Namun demikian nilai lendutan aktual di tengah bentang sebesar 46,651 mm masih memenuhi syarat karena kurang dari lendutan ijin 50 $\mathrm{mm}$.
\end{abstract}

Kata kunci: jembatan kereta api, welded through truss, PM 60 Tahun 2012, rasio tegangan dan defleksi

\begin{abstract}
This study analyzed the performance design about the uper structure of typical railway bridge for the $50 \mathrm{~m}$ WTT (Welded Through Truss) steel frame railway bridge with double track. Planning criteria refer to Attachment to the Minister of Transportation Regulation No. 60 of 2012 for Technical Requirements for Railroad. The results are evaluated in terms of stress ratio and deflection. The analysis result show that the $50 \mathrm{~m}$ WTT (Welded Through Truss) steel frame railway bridge has several diagonal bars that produce a stress ratio $>1$, so it is necessary to add the thickness of the cross sectional profile or also to add a stiffener to the bridge structure. However the actual deflection value in the middle of the span of 46.651 $\mathrm{mm}$ still meets the requirements because it is less than the allowable deflection of $50 \mathrm{~mm}$.
\end{abstract}

Keywords: railway bridge, welded through truss, PM 60 of 2012, stress ratio and deflection 


\section{PENDAHULUAN}

Jembatan rangka baja tipe warren merupakan salah satu jenis jembatan yang dinilai efektif dan popular di Indonesia. Pada jembatan kereta api, tipe jembatan rangka baja yang banyak digunakan adalah warren truss tipe WTT (Welded Through Truss). Jembatan rangka baja WTT merupakan salah satu jenis jembatan rangka baja yang sudah digunakan di Indonesia sejak tahun 1990-an (Hung, B. G., 2018). Desain tipikal jembatan tipe ini dimuat dalam Gambar Standar untuk perencanaan jembatan kereta api di Indonesia, dengan ketersediaan bentangnya yang bervariasi.

Tata cara dan pelaksanaan desain jembatan kereta api di Indonesia dimuat dalam Standar Teknis Kereta Api Indonesia untuk Struktur Jembatan Baja Tahun 2006 serta Lampiran Peraturan Menteri Perhubungan No. 60 Tahun 2012 tentang Persyaratan Teknis Jalur Kereta Api. Penelitian ini dimaksudkan untuk mendapatkan hasil evaluasi perencanaan jembatan kereta api dengan menganalisis kinerja struktur atas pada Jembatan KA tipikal tipe WTT (Welded Through Truss) $50 \mathrm{~mm}$ melalui analisis tegangan, lendutan struktur, dan pengecekan kapasitas penampang.

\section{KAJIAN PUSTAKA}

\subsection{Jembatan Kereta Api Rangka Baja}

Jembatan kereta api rangka baja merupakan jembatan baja yang difungsikan untuk mengakomodir beban lalu lintas kereta api yang melintasi permukaan lantai jembatan (Nuranita, B., 2019). Secara umum, terdapat empat kelompok tipe jembatan baja kereta api sebagaimana tersebut dalam Tabel 1.

Tabel 1. Tipe Jembatan Baja Kereta Api

\begin{tabular}{ccc} 
Tipe & Gelagar & Rangka \\
\hline Dinding & Gelagar Dinding & Rangka Dinding \\
\hline Rasuk/Dek & Gelagar Rasuk/Dek & Rangka Rasuk/Dek \\
\hline
\end{tabular}

(Sumber: Kementerian Perhubungan, 2012)

Pada penelitian ini, digunakan jembatan kereta api tipe rangka dinding dengan rangka tertutup di bagian atasnya (through truss). Adapun bentuk rangka yang digunakan adalah tipe Warren.

\subsection{Struktur Jembatan Kereta Api Rangka Baja}

Perhitungan struktur jembatan kereta api rangka baja yang digunakan pada penelitian ini mengacu kepada Peraturan Menteri Perhubungan Lampiran PM 60 Tahun 2012 yang memuat persyaratan teknis jalur kereta api, persyaratan teknis jalan rel, dan persyaratan beban. Selain itu, kombinasi pembebanan pada penelitian ini mengacu kepada peraturan Pembebanan untuk Jembatan SNI 1725:2016. Hasil analisis struktur dievaluasi dalam nilai rasio tegangan, lendutan, dan pengecekan kapasitas penampang (tekan, tarik, lentur dan geser). Metode analisis yang digunakan adalah metode faktor beban ketahanan atau LRFD (Load and Resistance Factor Design), yang berkaitan dengan perancangan beban dan kekuatan terfaktor yang harus memenuhi persyaratan kemanan untuk semua jenis gaya dalam. Pengecekan yang dilakukan meliputi stabilitas pada batang tarik, batang tekan, dan elemen lentur dan geser.

\section{METODE PENELITIAN}

\subsection{Bagan Alir}

Diagram alir penelitian ini ditunjukan pada Gambar 1. 


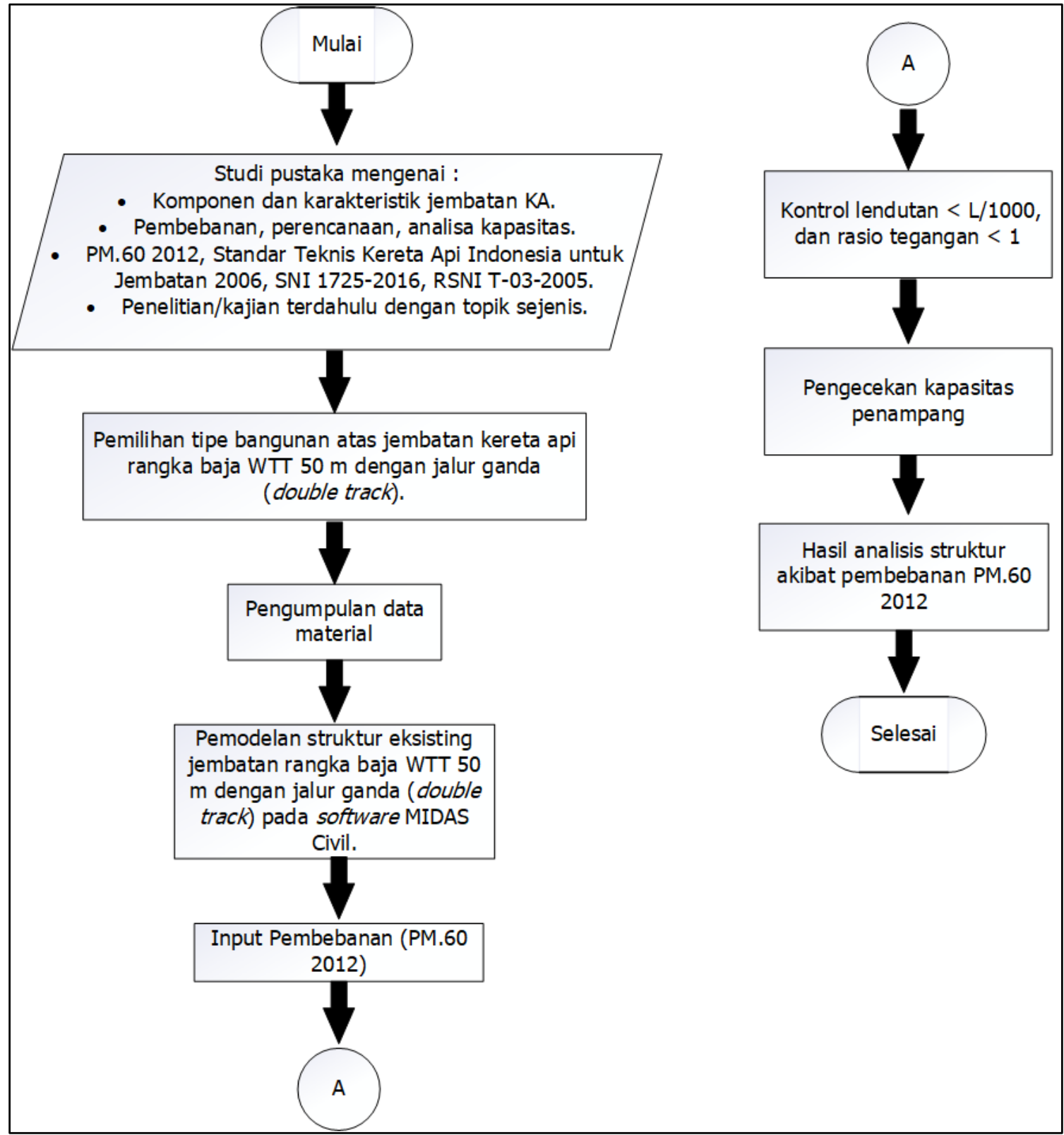

Gambar 1. Bagan alir penelitian

\subsection{Data Teknis}

Jembatan yang dianalisis adalah struktur jembatan tipe Warren dengan profil Welded Through Truss (WTT) bentang 50 m serta difungsikan untuk lalu lintas rel ganda (double track). Desain jembatan mengikuti Gambar Rencana Jembatan Tipikal yang tersedia di lapangan. Gambar rencana ini digunakan juga untuk jembatan KA yang dipasang di Lintas Selatan Jawa, CirebonKroya Segmen I (Antara Cirebon-Prupuk) dan Segmen III (Antara Purwokerto-Kroya). Fungsi jembatan untuk mengakomodir lalu lintas kereta api antar kota kelas jalan rel 1. Adapun data teknis jembatan ini yaitu pajang bentang $50 \mathrm{~m}$; jumlah segmen 5 buah; lebar jembatan $9 \mathrm{~m}$; jarak antar stringer $1,3 \mathrm{~m}$; dan tinggi jembatan $10 \mathrm{~m}$. Secara fungsional; jembatan ini diperuntukkan bagi lebar jalan rel $1.067 \mathrm{~mm}$; dengan kecepatan maksimum rencana 120 $\mathrm{km} / \mathrm{jam}$; beban gandar maksimum 18 ton; tipe rel R.54; serta jenis bantalan kayu dengan ukuran panjang $2 \mathrm{~m}$; lebar 0,26 $\mathrm{m}$ dan tebal 0,22 m serta jarak antar bantalan 0,6 $\mathrm{m}$. 
Material baja yang digunakan untuk batang atas, batang bawah, batang diagonal, tiang ujung, batang desak lateral, gelagar memanjang, ikatan angin atas, ikatan angin bawah, ikatan tumbuk yaitu SM400 ( $\left.F_{u}=400 \mathrm{MPa}, F_{y}=235 \mathrm{MPa}\right)$ dan gelagar melintang menggunakan SM490 ( $\left.F_{u}=490 \mathrm{MPa}, F_{y}=315 \mathrm{MPa}\right)$. Selanjutnya, gambar standar bangunan atas Jembatan KA WTT 50 meter double track ditampilkan pada Gambar 2 berikut.

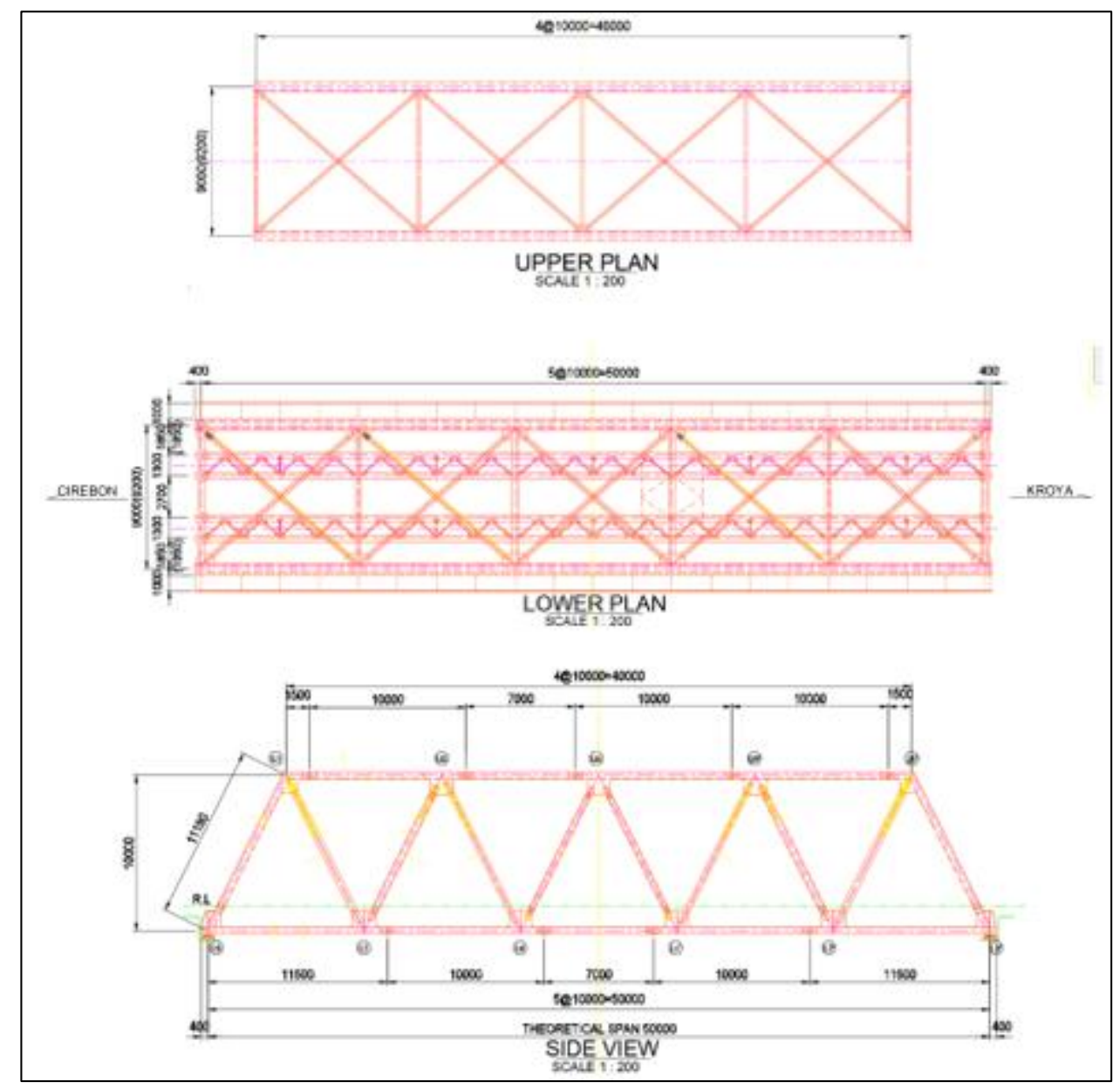

\section{Gambar 2. Denah dan tampak memanjang jembatan (Sumber: Gambar Standar Jembatan KA WTT Double Track Bentang 50 m)}

\subsection{Pemodelan Struktur Jembatan}

Pemodelan struktur jembatan ini dimodelkan melalui bantuan software MIDAS Civil secara 3D, seperti dapat dilihat pada Gambar 3. Dalam pemodelan struktur tersebut, di-input-kan data material dan bentul profil penampang sesuai Gambar Standar Jembatan KA WTT (Welded Through Truss) $50 \mathrm{~m}$ yang mana software MIDAS Civil secara otomatis menghitung beban mati sendiri pada struktur jembatan tersebut berdasarkan luas penampang setiap elemen dan berat jenis material. 


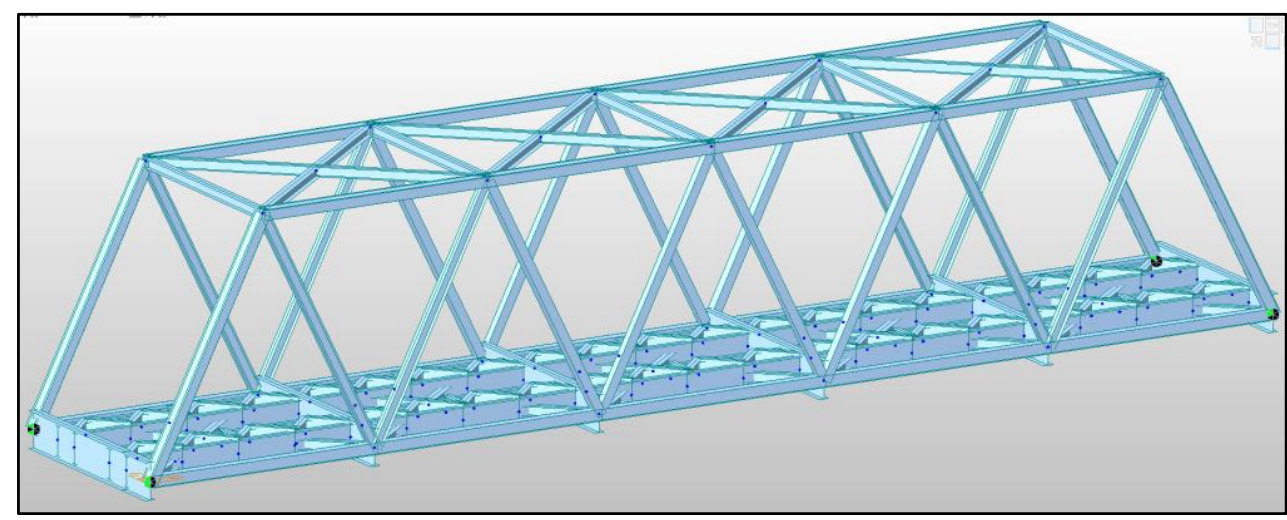

Gambar 3. Pemodelan struktur jembatan tampak 3D pada software MIDAS Civil

\section{ANALISIS DAN PEMBAHASAN}

\subsection{Pembebanan dan Kombinasi}

Pembebanan pada struktur jembatan ini yaitu:

1. Beban Mati Sendiri (MS)

Merupakan berat keseluruhan struktur rangka yang terdiri dari gelagar memanjang, gelagar melintang, rangka batang utama (batang bawah, batang atas, batang diagonal, dan rangka tiang ujung), batang desak lateral, ikatan angin atas dan bawah, ikatan tumbuk. Pada pemodelan, berat sendiri struktur akan dihitung di MIDAS Civil. Default program MIDAS Civil akan menghitung berat sendiri struktur secara otomatis berdasarkan luas penampang setiap elemen dan berat jenis material.

2. Beban Mati Tambahan (MA)

Beban mati tambahan dalam hal ini terdiri dari beban bantalan, beban rel, beban penambat dan baut, dan beban jembatan pejalan kaki (walkway). Maka didapatkan nilai total beban mati tambahan yang diterima masing-masing gelagar senilai 0,291 ton/m atau 2,854 kN/m.

3. Beban Hidup (L)

Beban hidup kereta berdasarkan Rencana Muatan 1921 (RM-21) yang dimuat dalam Peraturan Menteri No. 60 Tahun 2012. Pada pemodelan ini, terdapat 6 jenis beban kereta api yang digunakan, yaitu (lokomotif $(\mathrm{L})$, tender/carier (C), dan gerbong/Wagon (W)), 7 gandar dengan berat muatan gandar 15 ton, 5 gandar dengan berat muatan gandar 17 ton, 3 gandar dengan berat muatan gandar 18 ton, 2 gandar dengan berat muatan gandar 19 ton, 1 gandar dengan berat muatan gandar 20 ton seperti tampak pada Tabel 2. Masing-masing beban tersebut dimodelkan baik secara beban statik maupun beban bergerak (moving load), sehingga dihasilkan beban hidup maksimum dari kombinasi beban-beban hidup tersebut untuk kemudian dapat dikombinasikan bersama beban-beban lainnya.

Pendefinisian beban hidup bergerak (moving load) pada struktur dimodelkan dengan memberikan beban gandar dengan kondisi 1 yaitu kereta bergerak hanya pada lajur pertama saja, kondisi 2 yaitu kereta bergerak pada lajur yang kedua saja, dan kondisi 3 yaitu kereta bergerak bersama-sama pada lajur pertama dan kedua. Sedangkan pendefinisian beban hidup statik dilakukan dengan memasukan beban merata sebesar 8,75 ton/m sesuai dengan Rencana Muatan 1921 (RM-21) pada dua gelagar memanjang jembatan dengan total beban hidup merata yang diterima masing-masing gelagar 4,375 ton $/ \mathrm{m}$ atau $42,92 \mathrm{kN} / \mathrm{m}$. 
Tabel 2. Skema Pembebanan Rencana Muatan 1921

Rencana Muatan 1921 (RM 21)

Sebagai beban hidup dianggap suatu susunan kereta api terdiri dari dua lokomotif dengan tender:

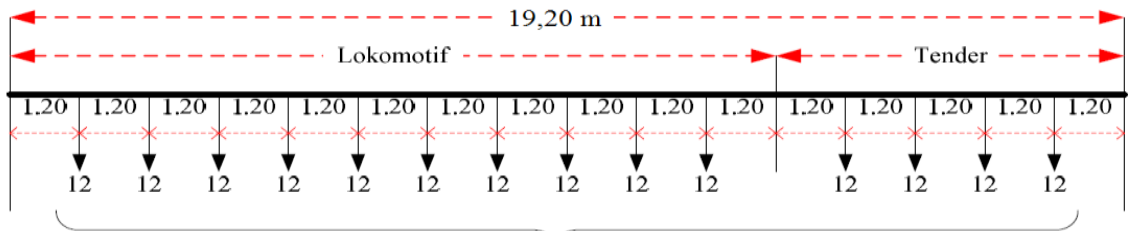

Jumlah Berat 168 ton atau 8,75 ton/m

Bila dengan kereta/gerbong yang banyaknya tidak tertentu:

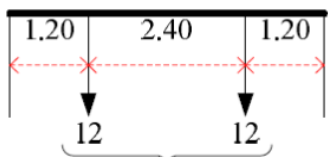

Jumlah 24 ton atau 5 ton/m

Susunan kereta itu selalu dibuat sehingga paling berbahaya bagi bagian yang dihitung kekuatannya.

Jika ada 6 atau 7 gandar yang dapat tempat dalam hitungannya, maka beratnya muatan gandar harus ditambah sampai 15 ton.

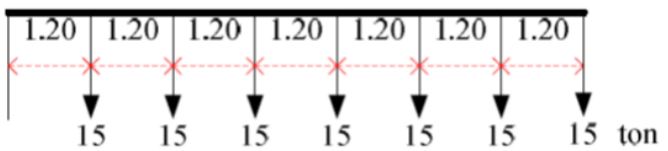

Jika hanya ada 5 gandar yang dapat tempat dalam hitungannya, maka beratnya muatan gandar harus ditambah sampai 17 ton.

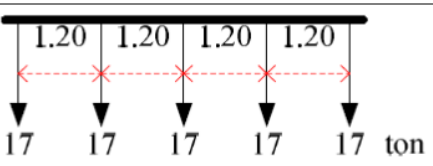

Jika hanya ada 3 gandar yang dapat tempat dalam hitungannya, maka beratnya muatan gandar harus ditambah sampai 18 ton.

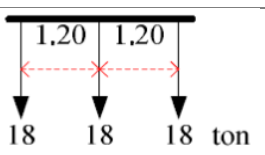

Jika hanya ada 2 gandar yang dapat tempat dalam hitungannya, maka beratnya muatan gandar harus ditambah sampai 19 ton.

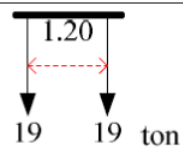

Jika hanya ada 1 gandar yang dapat tempat dalam hitungannya, maka beratnya muatan gandar harus ditambah sampai 20 ton.

Dari rencana muatan tersebut, selalu dipilih yang rencana yang hasilnya paling berbahaya bagi bagian yang dihitung kekuatannya

\section{(Sumber: Kementerian Perhubungan, 2012)}

4. Beban Kejut (TD)

Beban kejut sebesar 19,309 kN/m untuk tiap gelagar memanjang.

5. Beban Lateral Kereta (TL)

Beban lateral kereta sebesar 6,443 kN/m untuk tiap gelagar memanjang.

6. Beban Rem dan Traksi (TB)

Beban rem dan traksi sebesar 0,687 kN/m; beban bekerja pada ketinggian $1,8 \mathrm{~m}$. 
7. Beban Rel Panjang Longitudinal (LR)

Beban rel panjang longitudinal sebesar $5 \mathrm{kN} / \mathrm{m}$ untuk tiap gelagar memanjang.

8. Beban Angin (EW)

Berdasarkan SNI 1725:2016, gaya total beban angin pada struktur jembatan (EWs) tidak boleh diambil kurang dari 4,4 N/mm pada bidang tekan dan 2,2 N/mm pada bidang hisap struktur rangka dan pelengkung. Sehingga pada perhitungan ini digunakan beban angin pada struktur terlihat pada Tabel 3.

Tabel 3. Beban Angin pada Struktur

\begin{tabular}{cccc}
\hline Angin & Elemen & Besaran & Satuan \\
\hline Angin Tekan & Batang Atas, Batang Diagonal, & 4,4 & $\mathrm{~N} / \mathrm{mm}$ \\
\cline { 1 - 3 } \cline { 3 - 4 } Angin Hisap & Batang Bawah, dan Rangka Ujung & 2,2 & $\mathrm{~N} / \mathrm{mm}$ \\
\hline
\end{tabular}

(Sumber: Badan Standardisasi Nasional, 2016)

Selain itu, struktur dirancang menahan gaya akibat tekanan angin pada kereta (EW $)$, halmana tekanan angin harus diasumsikan sebagai tekanan menerus sebesar 1,46 N/mm; arahnya tegak lurus dan bekerja $1.800 \mathrm{~mm}$ di atas permukaan rel.

9. Kombinasi Pembebanan

Kekuatan konstruksi jembatan dihitung dari kombinasi pembebanan yang memberikan beban terbesar pada komponen yang ditinjau. Berdasarkan SNI 1725:2016, kombinasi pembebanan terdiri dari kuat dan layan sebagai berikut:

$$
\begin{array}{ll}
\text { Kuat I } & =1,1 \mathrm{MS}+2 \mathrm{MA}+1,8(\mathrm{TK}+\mathrm{TD}+\mathrm{TB}+\mathrm{TL}) \\
\text { Kuat II } & =1,1 \mathrm{MS}+2 \mathrm{MA}+1,4(\mathrm{TK}+\mathrm{TD}+\mathrm{TB}+\mathrm{TL}) \\
\text { Kuat III } & =1,1 \mathrm{MS}+2 \mathrm{MA}+\mathrm{RL}+1,4 \mathrm{EW} \\
\text { Kuat IV } & =1,1 \mathrm{MS}+2 \mathrm{MA}+\mathrm{RL} \\
\text { Kuat V } & =1,1 \mathrm{MS}+2 \mathrm{MA}+\mathrm{RL}+0,4 \mathrm{EW}_{\mathrm{s}}+\mathrm{EW}_{\mathrm{I}} \\
\text { Layan I } & =\mathrm{MS}+\mathrm{MA}+\mathrm{RL}+\mathrm{TK}+\mathrm{TD}+\mathrm{TB}+\mathrm{TL}+0,3 \mathrm{EW}_{\mathrm{s}}+\mathrm{EW}_{\mathrm{I}}
\end{array}
$$

\subsection{Defleksi Struktur}

Peninjauan nilai defleksi bertujuan untuk mengetahui besaran penyimpangan yang dihasilkan oleh struktur akibat pembebanan yang diberikan. Menurut Peraturan Menteri Perhubungan No. 60 Tahun 2012, nilai defleksi struktur aktual untuk jembatan kereta api rangka baja disyaratkan tidak melebihi defleksi izinnya yakni sebesar $L / 1.000$.

Adapun besar defleksi yang dihasilkan akibat kombinasi beban Layan I yang merupakan parameter perhitungan nilai defleksi tertera pada Tabel $\mathbf{4}$ berikut.

Tabel 4. Beban Angin pada Struktur

\begin{tabular}{ccc} 
Node & Load & $\begin{array}{c}\text { DZ } \\
\text { [mm] }\end{array}$ \\
\hline 98 & Layan I & $-46,651$ \\
\hline 100 & Layan I & $-46,369$ \\
\hline 99 & Layan I & -46.341 \\
\hline 97 & Layan I & -46.214 \\
\hline 88 & Layan I & -45.089 \\
\hline
\end{tabular}


Defleksi jembatan yang dihasilkan dari pemodelan akibat beban layan pada struktur adalah 46,651 mm. Defleksi maksimum terjadi di tengah bentang yang ditunjukan oleh titik yang berwarna hitam pada Gambar 4 di bawah. Jika dibandingkan dengan nilai defleksi maksimum yang diijinkan sebesar $50 \mathrm{~mm}$, dapat diidentifikasi bahwa defleksi aktual pada struktur tidak melebihi defleksi izinnya dan struktur jembatan ini memenuhi syarat parameter kekakuan terhadap defleksi.

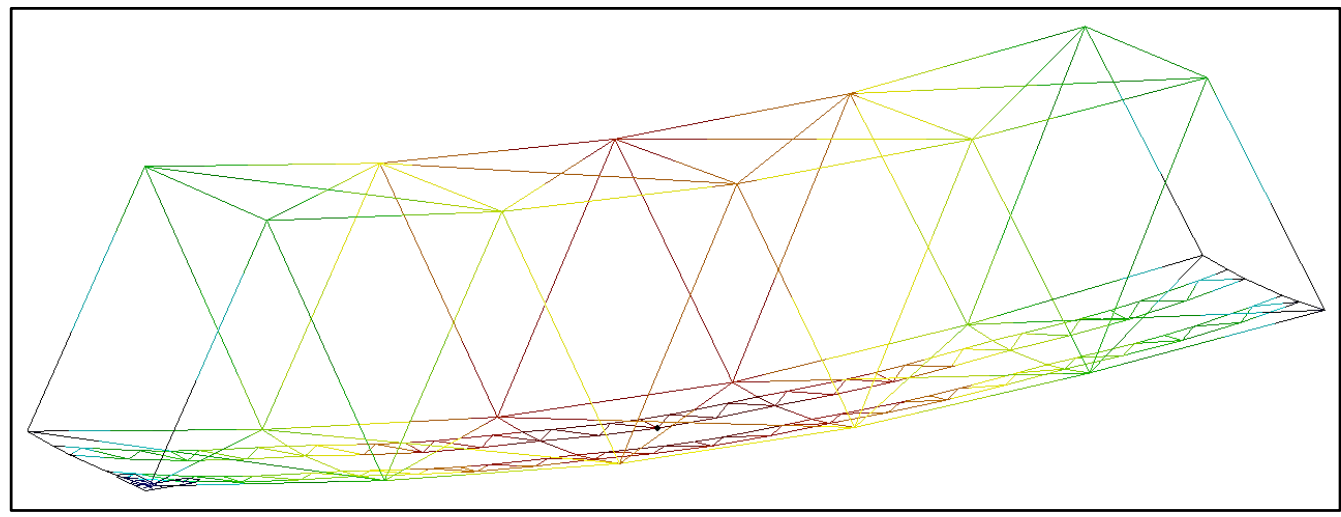

Gambar 4. Defleksi struktur

\subsection{Rasio Tegangan Struktur}

Pemeriksaan nilai rasio tegangan bertujuan untuk mengetahui apakah elemen-elemen struktur yang didesain sudah memenuhi kriteria aman atau belum berdasarkan perbandingan antara gaya dalam ultimit hasil kombinasi pembebanan maksimum dengan kekuatan nominal masingmasing elemen. Nilai rasio tegangan disyaratkan tidak melebihi angka 1.

Berdasarkan hasil pemeriksaan, dapat dilihat bahwa semua elemen struktur menghasilkan nilai rasio tegangan kurang dari 1 terkecuali pada elemen batang 14, 19, 33, dan 38 yang terjadi pada batang diagonal dengan nilai rasio tegangan 1,19-1,2 seperti diperlihatkan pada batang berwana merah pada Gambar 5 berikut ini.

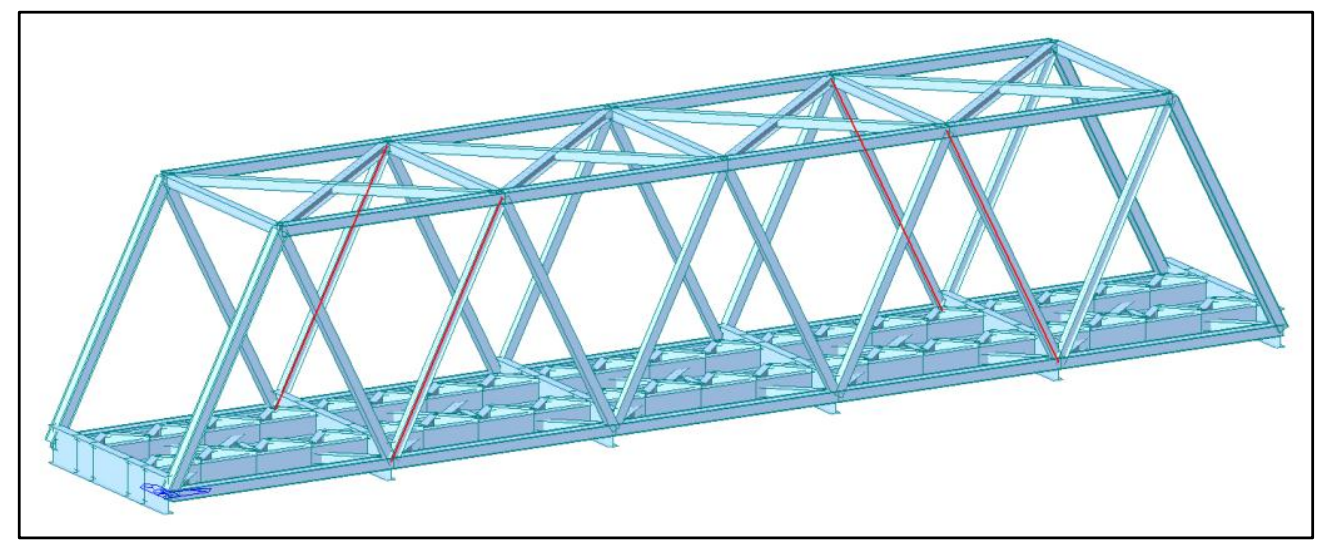

Gambar 5. Elemen kritis pada jembatan

Kombinasi terbesar yang menyebabkan terdapatnya batang kritis tersebut adalah akibat Kuat $\mathrm{I}\{1,1 \mathrm{MS}+2 \mathrm{MA}+1,8(\mathrm{TK}+\mathrm{TD}+\mathrm{TB}+\mathrm{TL})\}$. Salah-satu indikasi terjadinya hal tersebut adalah karena beberapa batang tidak mampu mengakomodir penyaluran beban akibat pembebanan Kuat I, khususnya akibat beban hidup statik yang memiliki nilai paling besar di antara beban lainnya. Berbeda dengan beban hidup moving load yang memodelkan beban kereta dengan lebih mendekati Kondisi aktual karena pada kenyataannya jembatan didesain untuk dilalui kereta saat bergerak, beban hidup statik memodelkan beban kereta dengan Kondisi kereta 
berhenti/diam di jembatan, namun kondisi demikian perlu dipertimbangkan supaya dapat menghasilkan kombinasi beban dengan kemungkinan terburuk. Oleh karena itu, dilakukan kembali pemodelan struktur pada jembatan yang sama, dengan data teknis dan pembebanan yang sama, namun tanpa memasukan beban hidup statik. Hasil analisis menunjukkan pemodelan kedua ini menghasilkan nilai rasio tegangan kurang dari 1 untuk seluruh elemen jembatan atau dikatakan memenuhi syarat kekuatan.

Namun demikian, terhadap batang-batang yang kritis, baiknya perlu dilakukan modifikasi/penanganan struktur sesuai kondisi/jenis teganga yang diderita batang, misalnya dapat berupa penambahan tebal profil penampang pada batang yang menderita aksial tarik ataupun perkuatan lain berupa penambahan stiffener pada batang yang menderita aksial tekan yang dalam kasus ini kondisi kritis diderita oleh batang tekan.

\subsection{Pengecekan Kapasitas Penampang}

Pengecekan kekuatan elemen baja yang diperhitungkan mencakup analisis kapasitas aksial tarik, aksial tekan, lentur dan geser. Dari gaya-gaya dalam yang dihasilkan, selanjutnya diambil satu gaya paling maksimum untuk tiap tipe batang, kemudian akan dianalisa apakah kapasitas elemen tersebut masih mampu mengakomodir beban terfaktornya atau tidak. Berikut ini pengecekan kapasitas lentur, geser, tarik, dan tekan pada elemen yang menerima gaya dalam paling maksimum sebagai berkut:

1. Pengecekan kapasitas lentur dan geser

Hasil analisis struktur pada MIDAS Civil menunjukan gaya batang maksimum pada gelagar

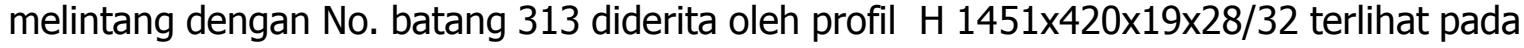
Gambar 6.

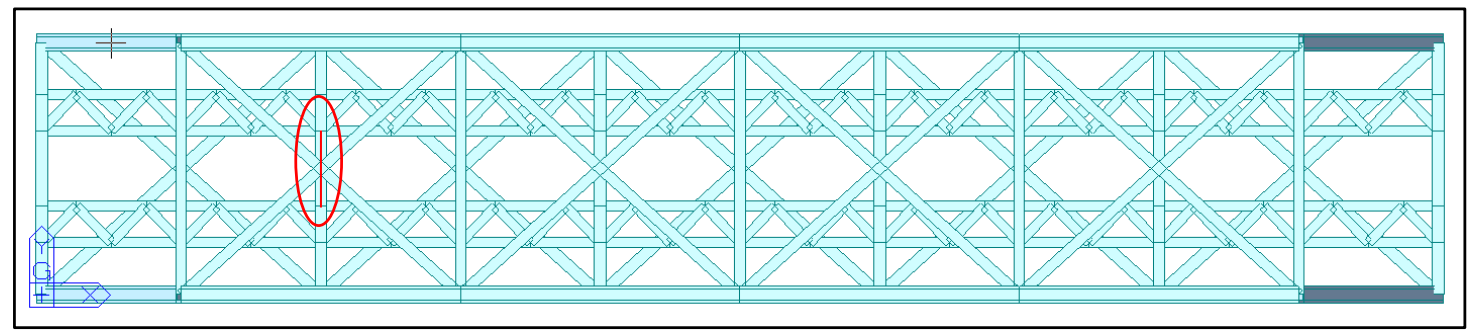

Gambar 6. Batang nomor 313 (gelagar melintang)

Berdasarkan hasil pengecekan penampang, didapatkan bahwa momen ultimit, $M_{u}=$ 4.843.226.249 Nmm $<\phi M_{n}=8.115 .413 .705 \mathrm{Nmm}$, maka batang kuat terhadap lentur. Geser ultimit, $V_{u}=272.907,49 \mathrm{~N}<\phi V_{n}=3.965 .322 \mathrm{~N}$, maka batang kuat terhadap geser.

2. Pengecekan kapasitas aksial tekan

Hasil analisis struktur MIDAS Civil menunjukan gaya batang maksimum pada batang atas dengan No. batang 9 diderita oleh profil Box 382x620x25x28 terlihat pada Gambar 7.

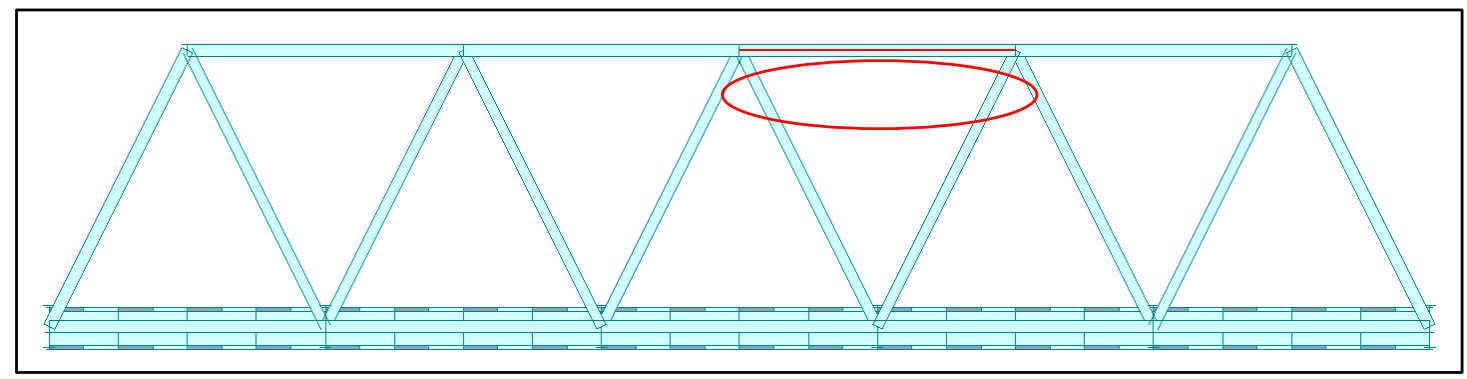




\section{Gambar 7. Batang nomor 9 (batang atas)}

Berdasarkan hasil pengecekan penampang, didapatkan bahwa aksial tekan ultimit, $P_{\text {utekan }}=-5.480 .741,295 \mathrm{~N}<\phi P_{n}=12.340 .210,19 \mathrm{~N}$, maka penampang memenuhi syarat kekuatan.

3. Pengecekan kapasitas aksial tarik Hasil analisis struktur MIDAS Civil menunjukan gaya batang maksimum pada batang bawah dengan No. batang 24 diderita oleh profil Box 388x620x19x22 terlihat pada Gambar 8.

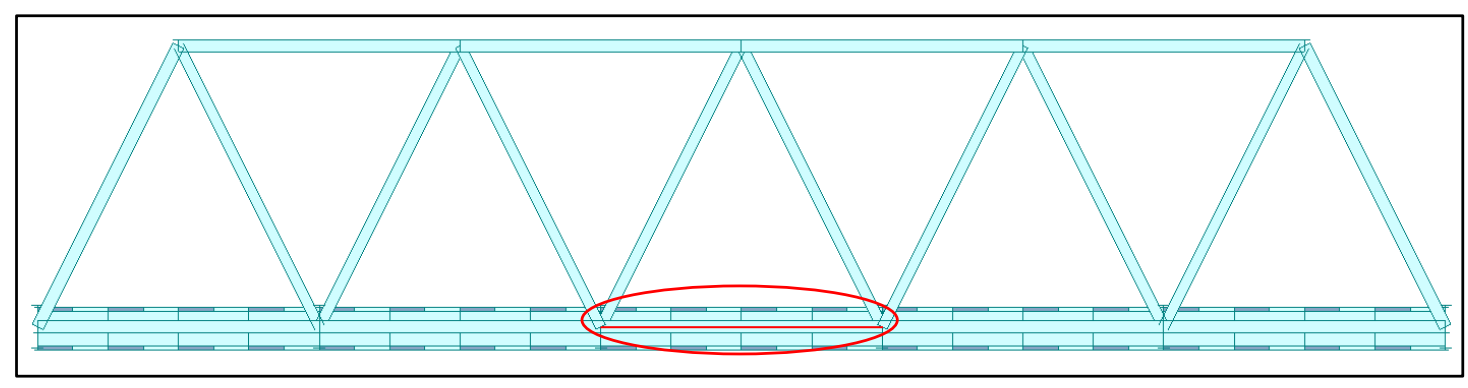

Gambar 8. Batang nomor 24 (batang bawah)

Berdasarkan hasil pengecekan penampang, didapatkan bahwa aksial tarik ultimit, $P_{u \text { tarik }}=$ $5.352 .994,641 \mathrm{~N}<\phi P_{n}=8.888 .076 \mathrm{~N}$, maka penampang memenuhi syarat kekuatan.

\section{KESIMPULAN DAN SARAN}

\subsection{Kesimpulan}

Berdasarkan hasil analisis yang telah dilakukan, maka didapatkan kesimpulan sebagai berikut:

1. Hasil analisis pada jembatan kereta api rangka baja tipe WTT bentang $50 \mathrm{~m}$ menghasilkan beberapa batang diagonal dengan rasio tegangan $>1$ yang berarti secara umum jembatan tidak memenuhi syarat kekuatan, sehingga perlu dilakukan modifikasi/penanganan struktur, misalnya berupa penambahan tebal profil penampang pada batang yang menderita aksial tarik ataupun pemberian stiffener pada batang yang menderita aksial tekan. Namun demikian, nilai lendutan aktual jembatan sebesar 46,651 mm kurang dari lendutan izinnya $50 \mathrm{~mm}$ sehingga jembatan memenuhi syarat kekakuan.

2. Hasil analisis jembatan tanpa kombinasi beban hidup statik menghasilkan elemen struktur dengan nilai rasio tegangan kurang dari 1 yang berarti struktur memenuhi syarat kekuatan. Sehingga dapat diketahui bahwa penggunaan beban hidup statik memiliki pengaruh yang sangat signifikan dalam pembebanan jembatan dibandingkan beban hidup bergerak (moving load).

3. Berdasarkan hasil pengecekan kapasitas penampang pada elemen-elemen tarik, tekan, lentur dan geser, semua batang memenuhi syarat kekuatan. Adapun kapasitas penampang lentur dan geser maksimum terjadi pada gelagar melintang, aksial tekan maksimum pada batang atas, dan aksial tarik maksimum pada batang bawah.

\subsection{Saran}

Berikut saran yang direkomendasikan dari penelitian ini yaitu terhadap beberapa pengasumsian yang dilakukan saat pemodelan seperti berat beban mati tambahan akibat penambat dan baut, berat jembatan pejalan kaki, dan sebagianya akibat keterbatasan data, pemodelan jembatan eksisting baiknya benar-benar dimodelkan sesuai kondisi aktual yang terjadi di lapangan. 


\section{DAFTAR RUJUKAN}

Badan Standardisasi Nasional. (2005). RSNI T-03-2005 tentang Perencanaan Struktur Baja untuk Jembatan. Jakarta: Badan Standardisasi Nasional.

Badan Standardisasi Nasional. (2016). SNI 1725:2016 tentang Pembebanan Untuk Jembatan. Jakarta: Badan Standardisasi Nasional.

Direktorat Jenderal Perkeretaapian. (2006). Standar Teknis Kereta Api Indonesia untuk Struktur Jembatan Baja. Jakarta: Kementerian Perhubungan.

Hung, B. G. (2018). Studi Perbandingan Struktur Jembatan Kereta Api Rangka Baja Tipe Tipikal WTT (Welded Through Truss) dengan Struktur Rangka Baja Profil WF (Wide Flange). Tugas Akhir. Bandung: Jurusan Teknik Sipil - Universitas Katolik Parahyangan.

Kementerian Perhubungan. (2012). Peraturan Menteri Perhubungan No. PM 60 Tahun 2012 tentang Persyaratan Teknis Jalur Kereta Api. Jakarta: Kementerian Perhubungan.

Nuranita, B. (2019). Analisis Kinerja Jembatan Kereta Api Tertutup Berdasarkan Draft Teknis Jalur Kereta Api untuk Kereta Berat (Heavy Train) 1435 mm. Tesis. Bandung: Jurusan Teknik Sipil - Institut Teknologi Bandung. 